\title{
Mathematical Communication Profile in Solving Probability Problems Reviewed by Self-efficacy of Prospective Mathematics Teachers
}

\author{
A. Shodiqin", Sukestiyarno, Wardono, Isnarto, S. B. Waluya, Rochmad \\ Department of Mathematics Education, Postgraduate Program, Universitas Negeri Semarang, Semarang, Indonesia
}

Received June 23, 2020; Revised August 3, 2020; Accepted August 25, 2020

\section{Cite This Paper in the following Citation Styles}

(a): [1] A. Shodiqin, Sukestiyarno, Wardono, Isnarto, S. B. Waluya, Rochmad, "Mathematical Communication Profile in Solving Probability Problems Reviewed by Self-efficacy of Prospective Mathematics Teachers, "Universal Journal of Educational Research, Vol. 8, No. 10, pp. 4661-4670, 2020. DOI: 10.13189/ujer.2020.081035.

(b): A. Shodiqin, Sukestiyarno, Wardono, Isnarto, S. B. Waluya, Rochmad, (2020). Mathematical Communication Profile in Solving Probability Problems Reviewed by Self-efficacy of Prospective Mathematics Teachers. Universal Journal of Educational Research, 8(10), 4661-4670. DOI: 10.13189/ujer.2020.081035.

Copyright $\mathrm{C} 2020$ by authors, all rights reserved. Authors agree that this article remains permanently open access under the terms of the Creative Commons Attribution License 4.0 International License

\begin{abstract}
Mathematical communication plays a very important role in learning mathematics, so it needs to be developed in mathematics learning. Mathematical communication is the process of conveying mathematical ideas to obtain a shared understanding between those who give and receive information. This study aims to describe the mathematical communication profile of prospective mathematics teachers based on self-efficacy in solving probabilistic problems. By solving probabilistic problems, it can improve probabilistic thinking, so that probabilistic problem solving can improve the ability to think at a higher level or Higher Order Thinking Skill, which is urgently needed today. This qualitative research is a study case. Subjects in this study were prospective mathematics teachers selected based on self-efficacy. The instruments used in this study were written tests and guided interviews based on probabilistic problems. Then the subjects were interviewed based on their work on the assignment. Data collection techniques are done through observation, interviewing, and documentation, while the data analysis technique used by researchers uses the Miles and Huberman model, namely by the process of (1) reduction data, (2) presentation data, and (3) drawing conclusions and verification. The results showed that prospective mathematics teachers who had different self-efficacy in solving probabilistic problems had different mathematical communication skills.
\end{abstract}

Keywords Mathematical Communication, Probabilistic Problem Solving, Self-efficacy

\section{Introduction}

Communication is urgent, in mathematics [1]. Communication is an urgent part of the five learning process skills that students must possess in learning mathematics, namely: reasoning and evidence, problem-solving, connections, communication, and representation [2]. Communication becomes an important part of mathematics and mathematics education. So in solving mathematical problems, mathematical communication skills are needed.

Mathematical communication is an important competency that must be developed in mathematics learning [3]. [4] state that mathematical communication is an aid in the transmission of mathematical knowledge or as a foundation in building mathematical knowledge. Whereas (Rich \& Aydin, 2016) states that mathematical communication is a process of conveying mathematical ideas so that a mutual understanding is obtained between those who gives and receives information. Communication and conceptualization of mathematics have a strong component contained in mathematics learning [5]. 
A student in solving the problems that contain an element of uncertainty usually uses the word possibility to present the degree of belief subjectively to the emergence of an event. How to think about something that is used to describe the way people to understand their world, to solve problems that contain an element of uncertainty, is called a probabilistic thinking model.

One interesting thought process to study is the probabilistic thinking process. Probabilistic is one of the mathematical sciences related to uncertainty. One branch of statistics relating to the problem of predicting and hoping is the probabilistic theory [6]. Next, probabilistic problem solving is solving problems related to probabilities that are not normally solved by routine procedures that have been mastered by students before.

Probabilistic thinking is a way to get non-routine problem solving from mathematical problems, this shows that probabilistic problem solving is a higher-order thinking skill (HOTS), because it characterizes high thinking. Three categories indicate the ability of Higher Order Thinking Skills (HOTS), namely: (1) bring up the transfer of one concept to another, (2) examine ideas and information critically, (3) use information to solve the problems [7].

There are several stages or categories in probabilistic thinking that have been built, including according to $[8]$ in developing probabilistic thinking has four phases, namely: classical stage, empirical concept stage, subjectivist concept stage, formal or axiomatic concept stage. Whereas [9] constructing probabilistic reasoning offers four categories, namely: (1) type of strategy, (b) representation, (c) use of probabilistic language, (4) nature of cognitive barriers.

Based on the results of research related to probabilistic thinking, including Sharma (2012) shows that the majority of students do not have a clear idea of probability construction, as well as probabilistic thinking can be developed in a learning environment with a design allowing students to explore, make guesses, and evaluate [10].

While the results of research from [11] also showed results that were not much different. A total of six VII grade students of SMP Negeri 13 Malang were the subject of the study, only 2 people were at level 4 , while 4 other people were at a level below 4. [12] students' probabilistic thinking processes cannot be seen from the age factor alone. Some students show that their level of probabilistic thinking is at a level below their age. While the results of the study [13] show that students who have field-dependent learning styles are at level 2 while independent fields are at level 4.

Three categories cause students to have difficulty in solving probabilistic problems: (1) understanding probabilistic problems, (2) choosing and using strategies that are suitable for solving the problems, (3) computational processes in solving the problems [14]. To optimize students' probabilistic thinking skills, proper probabilistic learning planning is required [14].

In solving problems one of them requires learning independence. Learning as a cognitive process is influenced by several factors including individual state factors, initial knowledge, attitude factors, individual factors, content, and presentation methods [15]. One of the important things of each individual which influences learning is self-regulated learning. Self-regulated learning is defined as a careful design process and self-monitoring of cognitive and affective processes in completing academic assignments [15][16]. The characteristics of learning independence describe the state of high individual personality and contain a metacognitive process in which the individual consciously designs, implements, and evaluates his learning and himself carefully. So that Self-efficacy is an unbiased part that can be released from learning independence. In the learning process students are influenced by the ability of mathematical connections and students' self-efficacy [17]. There is a positive relationship between self-efficacy and self-regulated learning [18].

Self-efficacy is one's belief in his ability to organize and implement a series of actions to achieve the desired outcome [19]. One of the attitudes that need to be held in learning mathematics is self-confidence which is identical to self-efficacy [20]. Self-efficacy is a student's self-confidence in his ability in learning mathematics. Mathematical self-efficacy is an important thing that can affect student learning and performance in the following lessons [21]. Based on research [22] in addition to mathematical communication skills, self-efficacy or self-confidence have a simultaneous influence on mathematical communication skills. According to[23] the higher one's self-efficacy is in their ability to formulate concepts, convey ideas, sharpen ideas to convince others, the higher their mathematical communication abilities. The higher the self-efficacy, the better the activities are carried out in various tasks and responsibilities [24]. Based on the results of the study [25] obtained information that students who have low self-efficacy, mathematical communication skills are also low.

Furthermore, communication becomes an essential part of mathematics and mathematics education. Communication is a way to share ideas and clarify the understanding [26]. This research is a theoretical and conceptual construction of instruments that can be used for mathematical communication processes of prospective mathematics teachers in solving probabilistic problems based on the perspective of learning independence. In solving the problems one of them is needed self-efficacy in learning. The results of this study can complement existing mathematical learning theories, especially those relating to mathematical communication, self-efficacy learning, and the development of probabilistic problem-solving abilities.

This research is expected to be able to construct 
theoretical and conceptual instruments so that they can be used for mathematical communication processes for prospective mathematics teachers in solving the probabilistic problems based on the perspective of self-efficacy. The results of this study can complement existing mathematical learning theories, especially those relating to the development of probabilistic problem-solving abilities. With the mathematical communication process of students in solving probabilistic problems with good, teachers are expected to know the extent of the ability of problem-solving by students. Completed solving by students can be used as a source of information for teachers to design appropriate learning so that learning can run optimally.

Based on the above background, the formulation of the problem in this study is: "how is the mathematical communication process in solving the probabilistic problems in terms of the self-efficacy mathematics teacher candidates?". So the purpose of this study is: "want to know the process of mathematical communication in solving the probabilistic problems in terms of self-efficacy mathematics teacher candidates".

\section{Materials and Methods}

\subsection{Research Method}

This descriptive of qualitative research analyzed the mathematical communication process in solving the probabilistic problems in terms of the personality of prospective mathematics teachers. Prospective mathematics teachers who take mathematics statistics courses are the subjects of this study.

\subsection{Analysis Techniques}

The data collection is done through observation, interviewing, and documentation [27]. Data analysis techniques use the model of Miles and Huberman, in terms of (1) the process of reduction data, (2) the process of presenting data; and (3) drawing conclusions and verification [28][29]. To validate the data, the technique triangulation method is used [30]. The triangulation technique uses the same source but uses different data collection techniques [31], as for the quantitative learning outcomes in terms of mathematical communication and self-efficacy learning in solving the probabilistic problems.

\subsection{Sampling and Instruments}

This research was conducted on 36 prospective mathematics teachers of mathematics education at University PGRI Semarang, Central Java. From 36 prospective mathematics teachers, 3 subject categories were selected based on their abilities. Data were collected in February and March 2020. Based on the easily accessible location, the problem raised following the existing problem, the selection of heterogeneous subjects, and then this study was conducted at the University of PGRI Semarang. Student subject research participants were selected using a purposive technique chosen based on self-efficacy with consideration of researchers and supporting lecturers. The instruments used in this study were questionnaires, written tests, and guided interviews based on the tasks raised by the problem. Before using the instrument, the instrument was first validated by three validators who were experts in mathematics education and were declared eligible to be used to analyze the mathematical communication profiles based on self-efficacy to solve probabilistic problems. The determination of the subject of self-efficacy is categorized based on low, medium, and high. The instrument was used was a questionnaire with a scale of 1 up to 4 (from strongly agree to strongly disagree). For subject selection you can see the following table:

Table 1. Participation in research

\begin{tabular}{ccc}
\hline Self Efficacy & Participant Code & $\begin{array}{c}\text { Selected Participant } \\
\text { With Code* }\end{array}$ \\
\hline Self Efficacy Low & $\mathrm{R}^{*}{ }^{*}, \mathrm{R} 2, \mathrm{R} 3, \mathrm{R} 4, \mathrm{R} 5, \mathrm{R} 6, \mathrm{R} 7, \mathrm{R} 8, \mathrm{R} 9$ & $\mathrm{R} 1$ \\
Self Efficacy Medium & $\mathrm{B} 1^{*}, \mathrm{~B} 2, \mathrm{~B} 3, \mathrm{~B} 4, \mathrm{~B} 5, \mathrm{~B} 6, \mathrm{~B} 7, \mathrm{~B} 8, \mathrm{~B} 9, \mathrm{~B} 10, \mathrm{~B} 11, \mathrm{~B} 12$, & $\mathrm{B} 1$ \\
Self Efficacy High & $\mathrm{H} 1^{*}, \mathrm{H} 2, \mathrm{H} 3, \mathrm{H} 4, \mathrm{H} 5, \mathrm{H} 6, \mathrm{H} 7, \mathrm{H} 8, \mathrm{H} 9, \mathrm{H} 10, \mathrm{H} 11, \mathrm{H} 12$, & $\mathrm{H} 1$ \\
\hline
\end{tabular}


In qualitative researchers the instrument or research tool is the researcher himself [27]. The research was assisted with assistive instruments, namely written tests, interview, and self-efficacy test instruments. The analysis data was carried out prior to the field, at the time in the field, up to the reporting of research results.

According to Stipek [32] suggested that learning strategies develop learner self-efficacy include:

(1) Specific teach strategies. Teach students specific strategies, such as outlining and summaries, which can improve their ability to focus on their assignments.

(2) Guide the students in setting goals. Help them make short-term goals after they make long-term goals. Short term goals mainly help students to assess their progress.

(3) Consider mastery. Give rewards to student performance, rewards that imply appreciation for the mastery of the material, not just rewards for doing assignments.

(4) Provide support for students, positive support coming from teachers, parents, and peers.

Self-efficacy is an individual's view of his abilities in certain academic fields, which places his position in overcoming situations and resolving the problems he faces. The self-efficacy indicators based on these definitions are: a) able to overcome the problem at hand, b) be sure of your own success; c) dare to face challenges; d) dare to take risks; e) be aware of her strengths and weaknesses; f) able to interact with other people; g) realizing his strengths and weaknesses [19] and Hoban, Serland Raine in [33].

Furthermore, there are several indicators related to communication skills, including according to [34] and [2], Mathematical PPPG TEAM in [35], While mathematical communication indicators follow [36], it is as follows: (1) mathematical ideas are reflected and classified, (2) the language of mathematical symbols is connected with everyday language, (3) reading, listening, evaluating skills, are used to interpret mathematical ideas, and (4) mathematical ideas are used to make guesses and make persuasive arguments. Communication indicators were chosen from the following opinions: (1) able to make arguments based on understanding problems and convincing conjectures, (2) able to solve and evaluate problems in writing based on understanding mathematical ideas, (3) presenting with mathematical tables and graphs, (4) can conclude the answer to the problem.

From the opinions of the existing mathematical communication indicators the indicators are chosen as follows, namely: (1) presenting mathematical statements in symbols, pictures, writing, and notations; 2) submitting conjectures and convincing arguments; 3 ) Written to be able to understand and evaluate probabilistic problem solving; 4) making conclusions with convincing arguments according to the questions.

The probabilistic problem raised is the problem that arises in the theory of opportunity and the function of the probability of arising, which arises in the probabilistic problem. After getting a subject in the category of self-efficacy, the following problems are given.

\section{Problem 1}

If $X$ stated how many mangoes were to be taken by Nurya from a bag containing 4 mangoes and 3 oranges, if he took 3 fruits at once, Question:

a). Describe the sample space of the incident?

b). Determine the possible opportunity function of the event?

c). Determine the variance of the number of mangoes taken by Nurya or Variant $(\mathrm{X})$ ?

\section{Results and Discussion}

From the selection of subjects based on self-efficacy by selecting 3 subjects namely subjects $\mathrm{R} 1, \mathrm{~B} 1$, and $\mathrm{T} 1$ and after the subject worked on the problem, the following results were obtained:

\subsection{Subjects with Low Self-efficacy}

Subject with Self-efficacy is subject R1, the following description is obtained: 


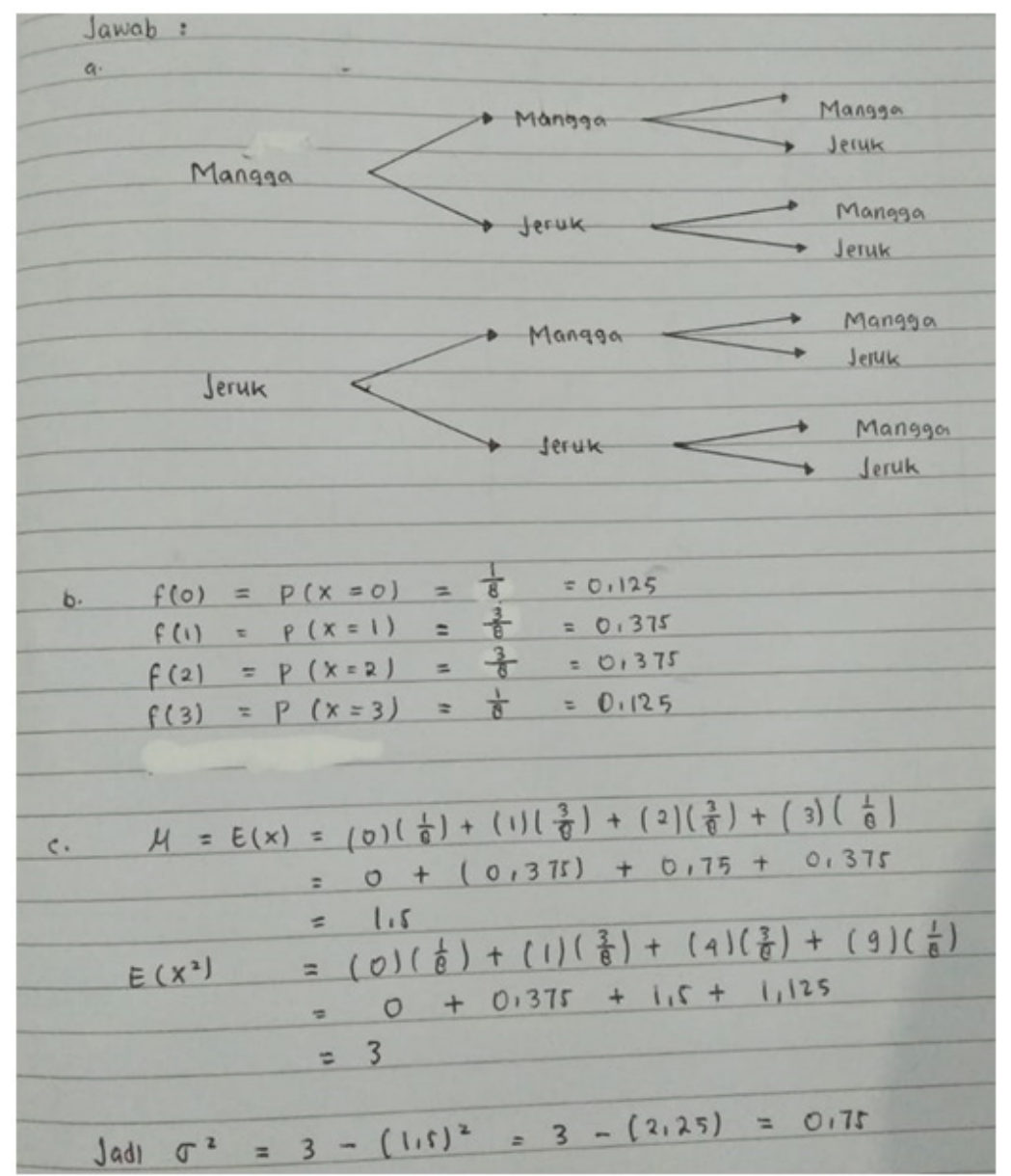

Figure 1. Answers from Subject R1

Based on Figure 1, the answer to subject R1, 1) Subject $\mathrm{R} 1$ in completing the description of the test it appears that $\mathrm{R} 1$ can be identified as his written communication skills in understanding the problem by writing things that are known and asked are still incomplete. The subject R1 has not been able to determine the alleged sample space and convincing arguments, this is shown from the answers that have not been able to describe the way of selecting the sample space object so that the resulting estimation in determining the opportunity function is not right. 2) Subject R1 is not perfect in presenting mathematical statements in a symbolic form in a box, it can be seen from describing the many ways of taking fruit in the bag. In the interview subject R1, it seems that his understanding of the preparation of objects is still lacking. Following on from the interview from subject R1.

Researcher : According to the diagram of answer number (a) already illustrate how to determine the sample space for the event?

Subject R1 : In my opinion, the diagram already reflects the way to determine the sample space, because the problem has already been explained 3 times.

3) Subject R1 has not been able to solve and evaluate the problems in writing based on an understanding of mathematical ideas, this is shown in writing the opportunity function and the value of variant $\mathrm{X}$ which is not correct. 4) the conclusions that have made are not following the questions asked and appear to be inconclusive.

\subsection{Subjects with Medium Self-efficacy}

From Figure 2 the answer of subject B1 in solving probabilistic problems shows that B1 can be identified as a mathematical communication profile as follows 1) in the beginning subject $\mathrm{B} 1$ can understand the problem by writing things that are known and asked. Subject B1 was also able to submit conjectures and arguments that convinced this was shown from the answers that could illustrate how to find sample space. 2) Subject B1 can present mathematical statements symbolically with tree diagrams, to illustrate the sample space. 3) Subject B1 can understand the problem, and answer the opportunity function of X, but Subject B1 is not shown the calculation process to get the opportunity function, in the evaluation of subject B1 has not been able to fully evaluate the answer correctly it is indicated by the calculation of $\mathrm{E}\left(X^{2}\right)$ or expectation value $X^{2}$ which, the concept in answering is correct but not quite right in its calculation. 

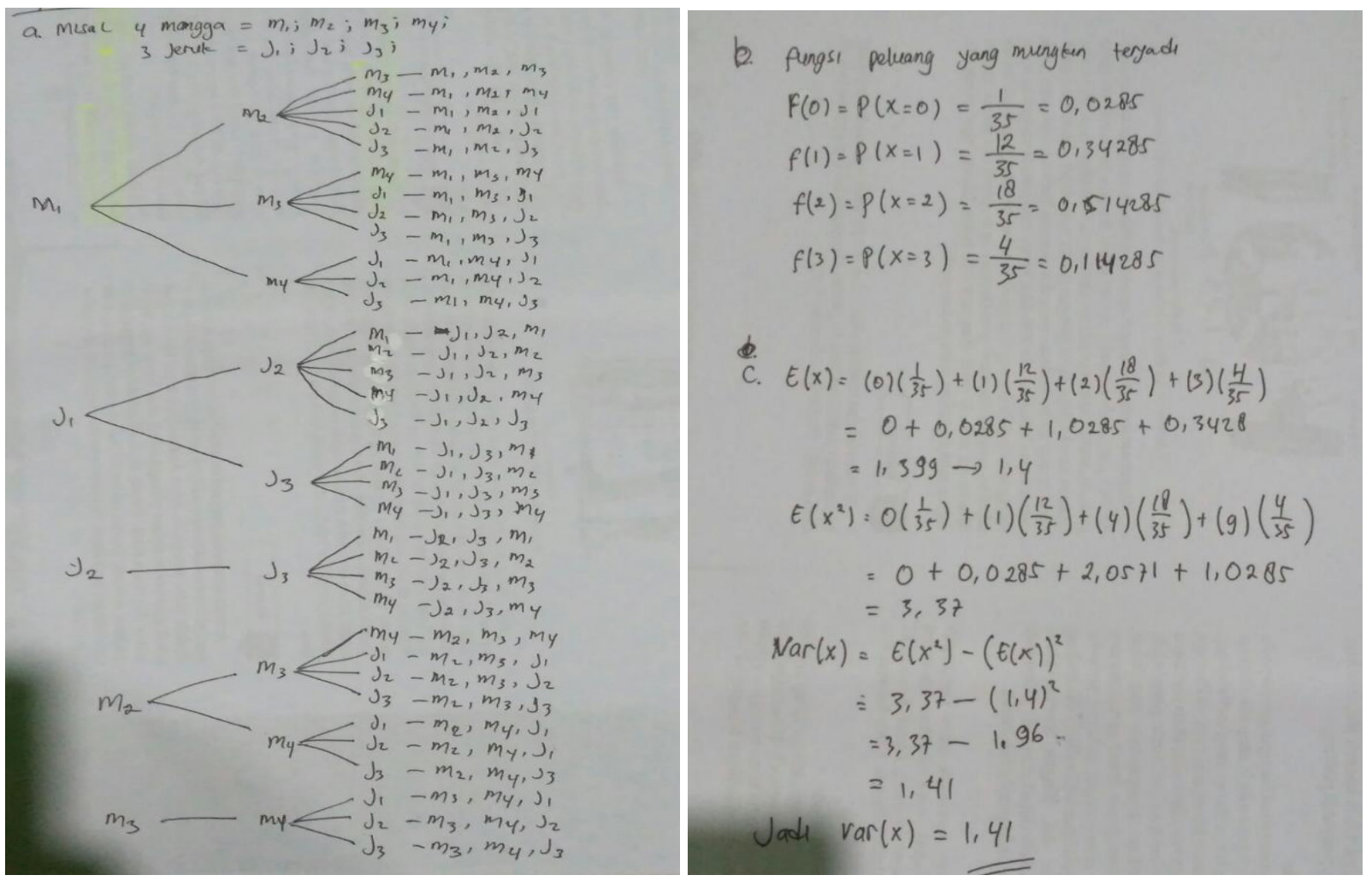

Figure 2. Answers from Subject B1

4) In making conclusions, subject $B 1$ in the argument has been convincing following the question, but there is an incorrect calculation in calculating the expectations of and Variant of $X$. The in-depth interview section with subject $\mathrm{B} 1$ is as follows:

\section{Researcher : How to determine the density function of opportunities?}

Subjek B1 : Starting from determining the sample space, then determining the opportunities.

Researcher : Why did not write down the process to get the opportunity density function?

Subjek B1 : By looking at what appears in the sample space on the tree diagram

Researcher : Are the calculations of $\mathrm{E}(\mathrm{X})$ and $\mathrm{E}$ $\left(X^{2}\right)$ matched?

Subjek B1 : The calculation of E $(\mathrm{X})$ is matched, but the calculation of which $\mathrm{E}\left(X^{2}\right)$ is still doubtful in its calculation.

\subsection{Subjects based on High Self-efficacy}

Subjects with high Self-efficacy are H1 subjects, obtained mathematical communication description in solving the probabilistic problems as follows:

From Figure 3 the answers of the $\mathrm{H} 1$ subject in completing the test, $\mathrm{H} 1$ can be identified in written mathematical communication in understanding probabilistic problem solving as follows: 1) H1 subjects can write things that are known and asked well, subject H1 is also able to propose alleged spaces random variables, to get the probability function from taking fruits in a bag and be able to make convincing arguments, this is shown from the answers that can illustrate how to determine the probability function of the random variable X. 2) subject H1 can present mathematical statements in a symbolic form box, but haven't yet completed in describing the sample space. 3) The H1 subject can solve and evaluate problems in writing based on an understanding of mathematical ideas, this is indicated by getting the results of the density of opportunity functions and variants of random variables $\mathrm{X}$. 4) subject $\mathrm{H} 1$ has been able to make the conclusions with convincing arguments following question 

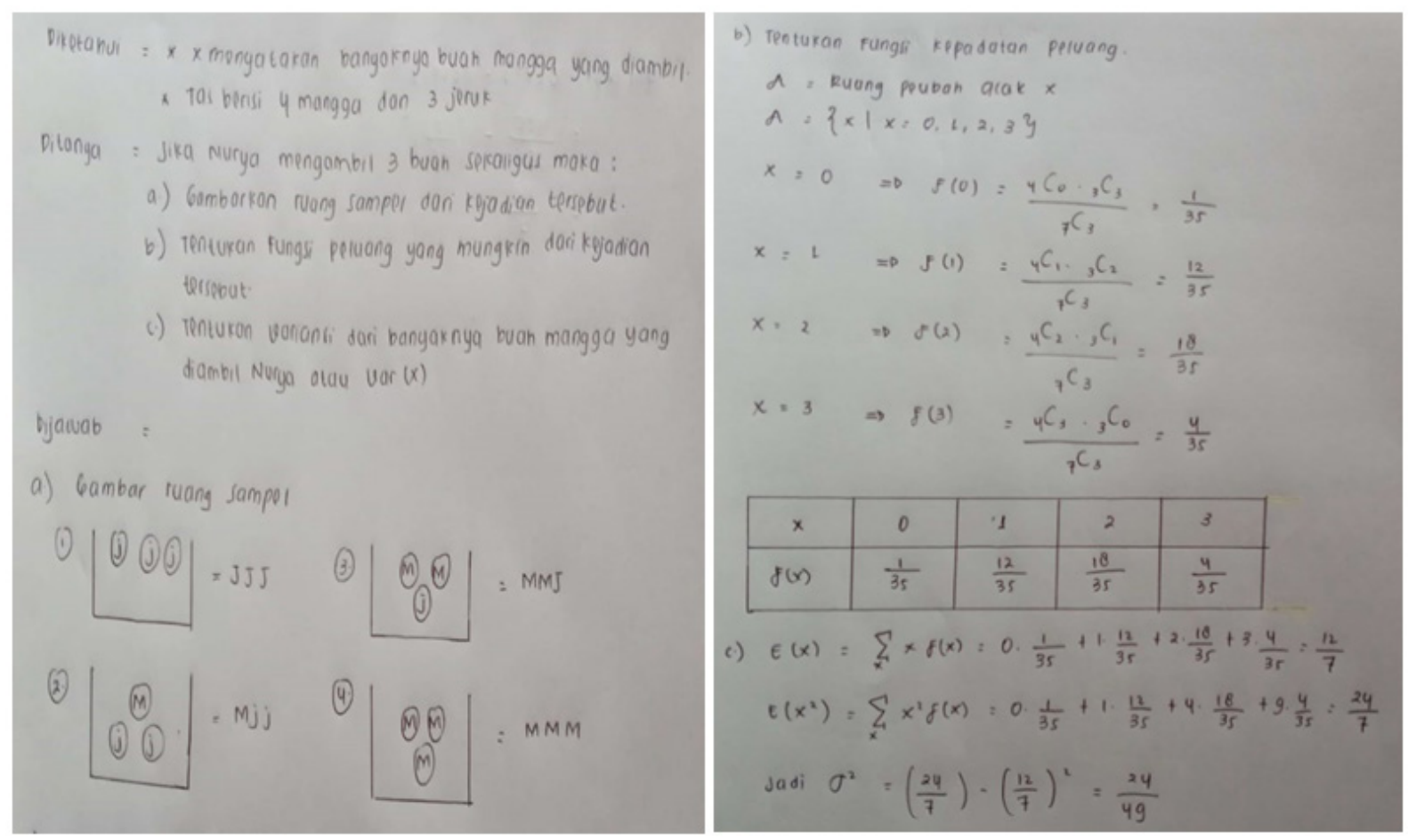

Figure 3. Answers from Subject $\mathrm{T} 1$

So that prospective mathematics teachers who have different self-efficacy in solving the probabilistic problems will have different communication skills. With the table in describing mathematical communication from the ability of self-efficacy is shown as follows:

Table 1. Mathematical communication based on self-efficacy in solving probabilistic problems

\begin{tabular}{|c|c|c|c|c|}
\hline No & $\begin{array}{l}\text { Mathematical } \\
\text { Communication } \\
\text { Indicator }\end{array}$ & Low Self-efficacy & Medium Self-efficacy & High Self-efficacy \\
\hline 1 & $\begin{array}{l}\text { Understand the } \\
\text { problem, and submit } \\
\text { conjectures by making } \\
\text { convincing arguments }\end{array}$ & $\begin{array}{l}\text { - Write things that are known } \\
\text { and asked, but not perfect } \\
\text { Has not been able to } \\
\text { determine the alleged } \\
\text { sample space and } \\
\text { convincing arguments }\end{array}$ & $\begin{array}{l}\text { - can write things that are } \\
\text { known and asked } \\
\text { Able to submit } \\
\text { conjectures and } \\
\text { convincing arguments }\end{array}$ & $\begin{array}{l}\text { - Can write things that } \\
\text { are known and asked } \\
\text { Able to propose } \\
\text { random variable } \\
\text { spaces }\end{array}$ \\
\hline 2 & $\begin{array}{l}\text { Present mathematical } \\
\text { statements in tables or } \\
\text { graphs }\end{array}$ & $\begin{array}{l}\text { Imperfect in presenting } \\
\text { mathematical statements } \\
\text { symbolically in the form of } \\
\text { boxes }\end{array}$ & $\begin{array}{l}\text { Able to present } \\
\text { mathematical statements } \\
\text { symbolically with tree } \\
\text { diagrams, to illustrate the } \\
\text { sample space. }\end{array}$ & $\begin{array}{l}\text { Able to present } \\
\text { mathematical } \\
\text { statements } \\
\text { symbolically in the } \\
\text { form of a box, but } \\
\text { not yet complete }\end{array}$ \\
\hline 3 & $\begin{array}{l}\text { Understand } r \text { and } \\
\text { evaluate mathematical } \\
\text { ideas for solving } \\
\text { problems }\end{array}$ & $\begin{array}{l}\text { - Have not been able to } \\
\text { understand and evaluate } \\
\text { mathematical ideas in } \\
\text { solving problems } \\
\text { Answering with the } \\
\text { concept is not right }\end{array}$ & $\begin{array}{l}\text { - Able to understand the } \\
\text { problem, and answer the } \\
\text { opportunity function of } X \\
\text { The concept used in } \\
\text { answering is correct } \\
\text { - Not being able to fully } \\
\text { evaluate the answers } \\
\text { correctly }\end{array}$ & $\begin{array}{l}\text { - Able to understand } \\
\text { and evaluate } \\
\text { mathematical ideas } \\
\text { in solving problems } \\
\text { in writing correctly } \\
\text { - Use the concept in } \\
\text { answering correctly }\end{array}$ \\
\hline 4 & $\begin{array}{l}\text { Conclude the answer to } \\
\text { the problem in } \\
\text { accordance with the } \\
\text { question }\end{array}$ & $\begin{array}{l}\text { The conclusion made is not } \\
\text { following the question }\end{array}$ & $\begin{array}{l}\text { - In the argument already } \\
\text { convinced according to } \\
\text { the question, } \\
\text { - Incorrect calculation }\end{array}$ & $\begin{array}{l}\text { Make conclusions } \\
\text { with convincing } \\
\text { arguments following } \\
\text { the question }\end{array}$ \\
\hline
\end{tabular}




\subsection{Discussion}

From the results obtained, differences in mathematical communication skills seen from self-efficacy are shown by three prospective mathematics teachers who were the subject of the study.

There are differences, each student communicates mathematically [37]. The results of interviewing with low self-efficacy subjects, subject R1 was able to understand the known and asked, but perfect, in solving the problem that can not determine the alleged sample space, and subject R1 has not been able to provide convincing arguments. Subject R1 is not perfect in presenting mathematical statements symbolically in the form of a box. The subject R1 in solving problems with concepts is still wrong, and this can be seen from not being able to understand the questions and evaluate the answers with mathematical concepts in answering questions. The conclusions are made by subject R1 are not in accordance with the question. While the results of research from [38] the profile of thinking of students with low mathematical ability in solving the probabilistic problems, the way of thinking System 1 is using intuition with students regarding aspects of the response, strategy, and representation.

For subject B1 being self-efficacy, Subject B1 wrote the things that are known and asked still complete, able to submit conjectures and convincing arguments. The subject can present the sample space symbolically with a tree diagram, subject $\mathrm{B} 1$ can understand the problem, and answer the opportunity function of X. Subject B1 can answer with the concept is correct, but has not been able to evaluate the answer correctly. In the argument have already convinced based on the question but the calculation is less precise. As for prospective mathematics teachers who have a high self-efficacy category of the four indicators of mathematical communication almost meet all indicators, but the symbolic presentation of mathematical statements in the form of a box can present, but is incomplete.

The needs for student identification in solving the probabilistic problems have various categories [14]. In solving the probabilistic problems, initial probabilistic thinking is needed for drawing differences between thoughts [39]. Self-efficacy will affect the learning of mathematics [32]. Prospective mathematics teachers who have constructivist beliefs view mathematics as a dynamic, developing, and a space for human creation, so further studies are needed regarding mathematics learning, including mathematical communication, and problem solving [40], [41]. The results of this study indicate that self-efficacy affects the mathematical communication of prospective mathematics teachers in solving the probabilistic problems.

\section{Conclusions}

Each prospective mathematics teacher has difference in mathematical communication skills shown by three prospective mathematics teachers who are the subject of research. With difference of abilities of self-efficacy students will affect the mathematical communication profile in solving the probabilistic problems. On the subject R1 with low self-efficacy ability, the mathematical communication ability is weak when dealing with probabilistic problem-solving questions that use symbols, but have not been able to answer the problem either verbally or in writing. Whereas the B1 sub-subject with self-efficacy in mathematical communication is quite good when dealing with probabilistic problem-solving questions that use symbols, able to use formulas to answer problems both verbally and in writing, but in the calculation of errors still occur, this results in a lack of evaluation in the process question.

While high self-efficacy in mathematical communication is good. High self-efficacy subjects in solving the probabilistic problems can use symbols and formulas to explain problems both verbally and in writing. The subject of high self-efficacy can make evaluations and conclusions in solving the probabilistic problems. From these three subjects, it can be concluded that prospective mathematics teachers who have a different self-efficacy in solving the probabilistic problems have different mathematical communication skills. Furthermore, research is needed to look at the barriers to mathematical communication and effectiveness in solving the probabilistic problems based on self-efficacy. The study of mathematical communication is solving the probabilistic problems in different aspects.

\section{Acknowledgments}

BPDN institutions have helped fund school fees so that this research can be conducted. Mathematics Education Study Program at Semarang PGRI University has facilitated the data collection process.

\section{REFERENCES}

[1] P. E. Paruntu, Y. L. Sukestiyarno, A. Priyono, and B. Prasetyo, "Analysis of Mathematical Communication Ability and Curiosity Through Project Based Learning Models With Scaffolding," Unnes J. Math. Educ. Res., vol. 7, no. 1, pp. 26-34, 2018.

[2] NCTM, Principle and Standards for School Mathematics. Reston VA: NCTM, 2000.

[3] A. Shodiqin, S. B. Waluya, Rochmad, and Wardono, "Mathematics communication ability in statistica materials based on reflective cognitive style," J. Phys. Conf. Ser., vol. 1511, p. 012090, 2020, doi: 10.1088/1742-6596/1511/1/012 090 . 
[4] N. Izzati and D. Suryadi, "Komunikasi Matematik dan Pendidikan Matematika Realistik," in Prosiding Seminar Nasional Matematika dan Pendidikan Matematika UNY, 2010 .

[5] M. Sedaghatjou, "Advanced mathematics communication beyond modality of sight," Int. J. Math. Educ. Sci. Technol., vol. 49, no. 1, pp. 46-65, 2018, doi: 10.1080/0020739X.2017.1339132.

[6] H.- Hodiyanto and D. Oktaviana, "Proses berpikir probabilistik mahasiswa pendidikan matematika ditinjau dari gender di IKIP PGRI Pontianak," JIPM (Jurnal Ilm. Pendidik. Mat., vol. 6, no. 2, p. 109, 2018, doi: 10.25273/jipm.v6i2.1963.

[7] Susan M. Brookhart, How To Assess Higher-Order Thinking Skills In Your Classroom. Alexandria, United States of America: ASCD, 2010.

[8] A. M. Nacarato and R. C. Grando, "The role of language in building probabilistic thinking," Stat. Educ. Res. J., vol. 13, no. 2, pp. 93-103, 2014.

[9] I. Jan and Miriam Amit, A four phase model for predicting the probabilistic situation of compound events. Israel: Ben-Gurion University, 2009.

[10] S. Sharma, "Probability from a socio-cultural perspective," Stat. Educ. Res. J., vol. 15, no. 2, pp. 126-144, 2016.

[11] Saiful Arif, "Proses Berpikir Siswa SMP pada Level Berpikir Probabilistik dalam Mengonstruksi Konsep Peluang Berdasarkan Teori APOS," Universitas Negeri malang, 2014.

[12] Mahyudi, "Proses Berpikir Probabilistik Siswa SMA dalam Mengkontruksi Konsep Permutasi dan Kombinasi," Edumatica, vol. 07, no. April, pp. 55-63, 2017.

[13] A. Tarom, "Probabilistic Thinking Ability of Students Viewed from Their Field Independent and Field Dependent Cognitive Style," in The 3rd International Conference on Mathematics, Science and Education 2016, 2016, doi: 10.1088/1742-6596/755/1/011001.

[14] D. P. Arum, T. A. Kusmayadi, and I. Pramudya, "Students' difficulties in probabilistic problem-solving," J. Phys. Conf. Ser., vol. 983, no. 1, 2018, doi: 10.1088/1742-6596/983/1/012098.

[15] B. .Kerlin, "Cognitive engagement style, self-regulated learning and cooperative learning," 1992. http://kerlins.net/bobbi/research/myresearch/srl.

[16] R. Bala, D. Sulisworo, and I. Maryani, "The analysis of self-regulation learning on elementary schools at the rural area in Indonesia," Univers. J. Educ. Res., vol. 8, no. 2, pp. 395-401, 2020, doi: 10.13189/ujer.2020.080209.

[17] H. U. Ningrum, "Mathematical Connection Ability Based on Self-Efficacy in IDEAL Problem Solving Model Assisted by ICT," vol. 9, no. 2, pp. 139-146, 2020.

[18] D. Lee, S. L. Watson, and W. R. Watson, "The relationships between self-efficacy, task value, and self-regulated learning strategies in massive open online courses," Int. Rev. Res. Open Distance Learn., vol. 21, no. 1, pp. 1-22, 2020, doi: 10.19173/irrodl.v20i5.4564

[19] A. Bandura, Self Efficacy: The Exercise of Control. New
York: W. H. Freman and Company, 1997.

[20] Risnawati, "Pengaruh model problem based instruction (PBI) dalam pendekatan aptitude treatment instruction terhadap pemahaman konsep siswa dan self-efficacy siswa di SMPN kota Pekanbaru," in Prosiding Seminar Nasional Matematika dan Pendidikan Matematika 2012, 2012.

[21] H. Z. Chan and M. N. L. Y. Abdullah, "Validity and reliability of the Mathematics Self-Efficacy Questionnaire (MSEQ) on primary school students," Pertanika J. Soc. Sci. Humanit., vol. 26, no. 4, pp. 2161-2177, 2018.

[22] Y. M. Muklis and K. C. . Sanhadi, "Kontribusi Self Efficacy dan Kemampuan Komunikasi Matematis Terhadap Prestasi Belajar Matematika Peserta didik," in In Prosiding Konferensi Nasional Penelitian Matematika dan Pembelajarannya (KNPMP 1), 2016.

[23] H. Hendriana and G. Kadarisma, "Self-Efficacy dan Kemampuan Komunikasi Matematis Siswa SMP," JNPM (Jurnal Nas. Pendidik. Mat., vol. 3, no. 1, p. 153, 2019, doi: 10.33603/jnpm.v3i1.2033.

[24] D. Herawaty, "Pengaruh Kecerdasan Emosional, Partisipasi Guru dalam Forum Ilmiah, Self efficacy, dan Motivasi Kerja terhadap Kinerja Guru Matematika," J. Rev. Pembelajaran Mat., vol. 1(1), pp. 71-85, 2016.

[25] D. Desmawati, R. Mariana, S. M.-P. 165 Journal, and U. 2015, "Hubungan Antara Self Efficacy Dengan Kemampuan Komunikasi Matematik Pada Siswa Smpn 2 Padang Panjang," Lppm.Upiyptk.Ac.Id, vol. 8, no. 2, 2015, [Online]. Available:

http://lppm.upiyptk.ac.id/psyche165/index.php/Psyche165/a rticle/view/59.

[26] A. Shodiqin and M. S. Zuhri, "Berpikir Impulsif Dalam Komunikasi Matematis Siswa Sekolah Menengah Pertama,' Pyhtagoras J. Progr. Stud. Pendidikan, URKB, vol. 7, no. 2, 2018.

[27] Y. L. Sukestiyarno, Metode Penelitian Pendidikan. Semarang: UNNES PRESS, 2020.

[28] M. B. Miles and A. M. Huberman, Qualitative data analysis: an expanded sourcebook ( $2 r d e d$ ). London: Sage Publication, 1994.

[29] Sugiyono, Metode Penelitian Kuantitatif, Kualitatif, dan $R \& D$. Bandung: Alfabeta, 2014.

[30] J. W. Creswell, Research Design Qualitative, Quantitative, and Moxed Method Approaches. California: SAGE Publications, Inc, 2014.

[31] Budiyono, Pengantar Metodologi Penelitian Pendidikan. Surakarta: UNS PRESS, 2017.

[32] L. Moma, "Self Efficacy Matematik Pada Siswa SMP," J. Pendidik. Mat., vol. 3, no. 2001, pp. 85-94, 2014.

[33] J. Wongsri, N., Cantwell, R.H., Archer, "The Validation of Measures of Self-Efficacy, Motivation and self-Regulated Learning among Thai tertiary Students. Paper presented at the Annual Conference of the Australian Association for Research in Education, Brisbane, December 2002," 2002, no. 1991, 2002.

[34] A. J. Baroody, Problem Solving, Reasoning \& Communicating, K-8: Helping Children Think 
Mathematically. New York: McMillan Publishing Company, 1993.

[35] S. L. Zanthy, Teori Kepribadian. Bandung: UPI dan Remaja Rosdakarya, 2011.

[36] LACOE (Los Angeles County Office of Education), "Communication," 2004. .

[37] J. S. Suriasumantri, Filsafat Ilmu Sebuah Pengantar Populer. Jakarta: Pustaka Sinar Harapan, 2007.

[38] R. Raya, "Profil Berpikir Probabilistik Siswa SMA dalam Menyelesaikan Masalah Probabilitas," SAINS, vol. 17, pp. 14-18, 2017.
[39] R. E. Groth, J. W. Austin, M. Naumann, and M. Rickards, "Toward a theoretical structure to characterize early probabilistic thinking," Math. Educ. Res. J., 2019, doi: 10.1007/s13394-019-00287-w.

[40] Muhtarom, D. Juniati, and T. Y. E. Siswono, "Examining prospective teachers' belief and pedagogical content knowledge towards teaching practice in mathematics class: A case study," J. Math. Educ., vol. 10, no. 2, pp. 185-202, 2019, doi: 10.22342/jme.10.2.7326.185-202.

[41] M. Muhtarom, A. Shodiqin, and N. Astriani, "Exploring senior high school student's abilities in mathematical problem posing," JRAMathEdu (Journal Res. Adv. Math. Educ., vol. 5, no. 1, pp. 69-79, 2020, doi: 10.23917/jramathedu.v5i1.9818. 